\title{
PENGARUH METODE PEMBELAJARAN DAN KEMANDIRIAN BELAJAR TERHADAP HASIL BELAJAR ILMU PENGETAHUAN SOSIAL
}

\author{
Yustia Suntari \\ e-mail: suntarie_07@yahoo.com \\ PGSD-FIP Universitas Negeri Jakarta
}

\begin{abstract}
Abstrak: Terdapat sejumlah variabel yang mempengaruhi hasil belajar. Penelitian ini tertarik meneliti pe-ngaruh metode pembelajaran dan kemandirian belajar terhadap hasil belajar dalam ilmu pengetahuan sosial. Penelitian ini bertujuan untuk mengetahui pengaruh metode pembelajaran dan kemandirian belajar terhadap hasil belajar mata pelajaran IPS di SDN Pluit 05 Pagi, Kecamatan Penjaringan, Jakarta Utara. Penelitian yang dilakukan Januari dan Februari 2011 ini, menggunakan desain faktorial 2x2. Hasil penelitian menunjukkan (a) hasil belajar siswa yang diberikan melalui pembelajaran dengan metode pembelajaran role playing lebih tinggi dibandingkan dengan siswa yang diberikan pembelajaran dengan metode pembelajaran ceramah, (b) hasil belajar siswa yang memiliki kemandirian belajar tinggi lebih tinggi dibandingkan dengan siswa yang memiliki kemandirian belajar rendah, (c) hasil belajar siswa yang mengikuti pembelajaran dengan metode pembelajaran role playing, bagi siswa yang memiliki kemandirian belajar tinggi, lebih tinggi dari siswa yang memiliki kemandirian belajar rendah, dan (d) hasil belajar siswa yang mengikuti pembelajaran dengan metode pembelajaran ceramah yang memiliki kemandirian belajar rendah, lebih tinggi dari siswa yang memiliki kemandirian belajar tinggi. Penelitian ini menyarankan agar guru lebih mampu menstimulasi dan melatih kemampuan dalam mengajarkan IPS dengan memberikan kebebasan seluas-luasnya kepada siswa untuk sesuai dengan gaya belajarnya.

Kata kunci: metode pembelajaran, role playing, kemandirian belajar, hasil belajar
\end{abstract}

\section{EFFECTS OF INSTRUCTIONAL METHODS AND INDEPENDENT LEARN- ING TOWARDS LEARNING ACHIEVEMENT IN SOCIAL SCIENCES}

\begin{abstract}
A number of variable affects the learning achievement but this research is interested in discovering the effect of instructional methods and independent learning towards the learning achievement in social science. The research aims at discovering the mentioned effect in Social Science at SDN Pluit 05 Pagi, Penjaringan Subdistrict, North Jakarta. The research discovered (a) the learning achivement with role playing method is higher compared to expository method, (b) students with high independent learning style has higher learning achievement compared to those having a lower one, (c) learning achievement of the students with high independent learning taught with role playing instruction is higher than those with low independent learning, and (d) learning achievement of the students with low independent learning taught with expository method is lower than those having high independent learning. Based on the findings, the research suggests the teachers to improve their skills in teaching social science and assist the students to learn based on their individual learning styles.
\end{abstract}

Keywords: instructional method, role playing, independent learning, learning achievement.

\section{PENDAHULUAN}

Dalam buku Kurikulum Tingkat Satuan Pendidikan (2006:2), pendidikan berfungsi mengembangkan kemampuan dan membentuk watak serta peradaban bangsa yang bermartabat dalam rangka mencerdaskan kehidupan bangsa, bertujuan untuk berkembangnya potensi peserta didik agar menjadi manusia yang beriman dan bertaqwa kepada Tuhan Yang Maha Esa, berakhlak mulia, sehat, berilmu, cakap, kreatif, mandiri, dan menjadi warga negara yang demokratis serta bertanggung jawab.

Selanjutnya, dalam Undang-Undang Republik

Perspektif Ilmu Pendidikan - Vol. 25 Th. XVI April 2012
Indonesia Nomor 20 Tahun 2003 (2003:1), Sistem Pendidikan Nasional harus mampu menjamin pemerataan kesempatan pendidikan, peningkatan mutu serta relevansi, dan efisiensi manajemen pendidikan untuk menghadapi tantangan sesuai dengan tuntutan perubahan kehidupan lokal, nasional, dan global sehingga perlu dilakukan pembaruan pendidikan secara terencana, terarah, dan berkesinambungan.

Berbicara tentang mutu pendidikan atau kualitas pendidikan yang diwakili oleh hasil belajar siswa, tidak dapat lepas dari faktor-faktor yang mempengaruhinya. Hasil belajar merupakan hasil interaksi antara berbagai faktor, baik faktor internal yang ber- 
asal dari siswa itu sendiri, seperti kemampuan, minat, bakat, motivasi intrinsik, dan kemandirian belajar siswa maupun faktor eksternal, seperti guru, materi pelajaran, metode pembelajaran yang digunakan oleh guru, sistem penilaian, sarana fisik, keluarga, dan masyarakat.

Dari sekian banyak faktor yang mempengaruhi hasil belajar, penelitian ini membatasi diri pada salah satu faktor eksternal saja sebagai variabel bebas, yakni faktor eksternal "metode pembelajaran" dan faktor "kemandirian belajar" siswa. Diduga kedua faktor tersebut mempengaruhi hasil belajar siswa. Hasil belajar yang akan diteliti adalah dalam mata pelajaran IPS kelas V di sekolah dasar.

Pemilihan masalah dalam studi ini dilatarbelakangi oleh adanya beberapa hasil temuan penelitian yang telah dilakukan oleh para peneliti terdahulu mengenai rendahnya mutu hasil belajar IPS di sekolah dasar. Misalnya, hasil observasi awal menunjukkan bahwa kecenderungan yang terjadi di lapangan dalam mempelajari Ilmu Pengetahuan Sosial, para siswa banyak menghafal jajaran angka, tahun, nama orang, dan tempat yang sangat membosankan (Depdikbud, 1990: 8).

Padahal di dalam proses pembelajaran, seharusnya setiap siswa selalu diarahkan agar menjadi siswa yang mandiri dan untuk menjadi siswa yang mandiri, siswa harus mencari sumber belajar sendiri, sehingga dapat dicapai suatu kemandirian belajar (Paulina Pane, 1994:5). Keberhasilan siswa dalam belajar sangat ditentukan oleh kemandirian dalam belajar, banyak siswa yang terbiasa belajar secara mandiri mempunyai kemampuan intelektual yang lebih baik daripada siswa yang hanya belajar pada saat di kelas saja.

Selain itu, dengan kemandirian belajar siswa terbiasa mampu menyelesaikan masalahnya sendiri termasuk tugas belajar yang dibebankan oleh guru. Hal terpenting dari kemandirian belajar bagi siswa adalah tertanamnya keyakinan yang kuat untuk memilih dan menggunakan hasil belajar yang diperoleh untuk kepentingan masa depannya.

Uraian di atas memberi kejelasan bahwa terdapat sisi kelemahan pembelajaran IPS pada anak SD, belum mencapai kemampuan yang optimal dalam menemukan sikap sosial. Oleh karena itu, perlu ada upaya untuk dapat meningkatkan kemampuan menemukan konsep kepada siswa SD. Salah satu upaya tentu berpulang kepada tugas guru, misalnya dengan menyiasati proses pembelajaran dengan berbagai variasi strategi pembelajaran dan memperhatikan kemandirian belajar bagi masing-masing siswa.
Bertitik tolak dari beberapa pernyataan dan fakta yang dihasilkan dari beberapa penelitian di atas, maka melalui penelitian ini akan dikaji "Pengaruh dari metode pembelajaran dan kemandirian belajar terhadap hasil belajar IPS di sekolah dasar". Bertitik tolak dari pembatasan masalah tersebut, maka yang menjadi masalah pokok dalam penelitian ini adalah "Apakah ada pengaruh metode pembelajaran dan kemandirian belajar terhadap hasil belajar pada mata pelajaran IPS siswa sekolah dasar?" Masalah pokok tersebut dijabarkan dalam pertanyaan penelitian sebagai berikut.

1. Apakah terdapat perbedaan hasil belajar antara siswa yang mengikuti pembelajaran dengan metode role playing dan siswa yang mengikuti pembelajaran dengan metode ceramah dalam mata pelajaran IPS di sekolah dasar?

2. Apakah terdapat perbedaan hasil belajar antara siswa yang memiliki kemandirian belajar tinggi dan siswa yang memiliki kemandirian belajar rendah dalam mata pelajaran IPS di sekolah dasar?

3. Apakah terdapat perbedaan hasil belajar siswa yang kemandirian belajar tinggi yang mengikuti pembelajaran dengan metode role playing dan siswa yang mengikuti pembelajaran dengan metode ceramah dalam mata pelajaran IPS di sekolah dasar?

4. Apakah terdapat perbedaan hasil belajar siswa yang memiliki kemandirian belajar rendah yang mengikuti pembelajaran dengan metode role playing dan siswa yang mengikuti pembelajaran dengan metode ceramah dalam mata pelajaran IPS di sekolah dasar?

5. Apakah terdapat pengaruh interaksi antara metode pembelajaran dengan kemandirian belajar terhadap hasil belajar dalam mata pelajaran IPS di sekolah dasar?

6. Apakah terdapat perbedaan yang signifikan hasil belajar IPS yang diberi metode pembelajaran ceramah bagi siswa yang mempunyai kemandirian belajar tinggi dengan siswa yang mempunyai kemandirian belajar rendah?

7. Apakah terdapat terdapat perbedaan yang signifikan hasil belajar IPS dengan metode pembelajaran role playing bagi siswa yang memiliki kemandirian belajar tinggi dengan siswa yang memiliki kemandirian belajar rendah?

\section{Kajian Teoretis}

\section{Hasil Belajar}

Bloom (1956: 7-18) menyatakan bahwa hasil belajar adalah perolehan warga belajar setelah mengikuti proses belajar dan perolehan belajar meli- 
puti tiga bidang kemampuan, yaitu kognitif, afektif, dan psikomotorik. Kemampuan kognitif, meliputi perolehan hasil belajar dengan tingkat pengetahuan, pemahaman, penerapan, analisis, sintesis, dan evaluasi. Kemampuan afektif, meliputi jenjang penerimaan, pemberian respon, penilaian, pengorganisasian, dan karakteristik. Sedangkan kemampuan psikomotorik, meliputi tingkat persepsi kesiapan, gerakan terbimbing, gerakan biasa, dan gerakan kompleks, menyesuaikan pola gerakan dan kreativitas.

Anderson dan Krathwohl (2001:27-30) berpendapat bahwa hasil belajar mencakup dua dimensi, yakni (1) dimensi pengetahuan yang terdiri dari pengetahuan faktual, pengetahuan konseptual, pengetahuan prosedural, dan pengetahuan metakognitif, dan (2) dimensi proses kognitif yang terdiri dari mengingat, pemahaman, penerapan, analisis, evaluasi, dan kreasi. Rumusan tujuan (taxonomy) yang dikemukakan Anderson, merupakan hasil revisi dari taksonomi Bloom.

Dari uraian di atas, maka yang dijelaskan kriteria untuk mengetahui hasil belajar siswa dalam penelitian ini adalah yang berhubungan dengan kemampuan dalam pengetahuan (knowledge), yaitu; (1) pada tipe utama dan sub-sub tipe, meliputi pengetahuan faktual, pengetahuan konseptual, pengetahuan prosedural dan pengetahuan metakognisi, dan (2) pada kategori proses, meliputi mengingat, memahami, menerapkan, menganalisis, evaluasi, dan mencipta. Hasil belajar itu dimanifestasikan dalam wujud pertambahan materi pembelajaran dalam dimensi pengetahuan (knowledge) yang berupa fakta, info prinsip atau hukum atau kaidah prosedur atau pola kerja.

\section{Ilmu Pengetahuan Sosial (IPS)}

Ilmu Pengetahuan Sosial (IPS) menurut Mutakin (1997:8) adalah suatu studi tentang hubungan manusia dalam satu keragaman pola yang bertujuan untuk mengembangkan warga masyarakat yang memiliki ilmu pengetahuan, proses berpikir, sejumlah keterampilan, sikap, dan nilai serta kurikulum yang bertumpu pada pondasi-pondasi, disiplin ilmu sosial, psikologi, historis, dan filosofis. Dalam pemahaman IPS ada enam dimensi yang harus diperhatikan, yakni intelektual, personal, sosial, kultural, waktu, dan dimensi ruang dan tempat.

Sedangkan Somantri dalam Daldjoeni (1992: 9) menjelaskan bahwa IPS itu mempunyai arti sebagai pelajaran ilmu-ilmu sosial yang disederhanakan untuk pendidikan tingkat SD, SLTP, dan SLTA. Menyederhanakan mengandung arti (1) menurunkan tingkat kesukaran ilmu-ilmu sosial yang biasanya dipelajari di universitas, menjadi pelajaran yang sesuai dengan kematangan berpikir para siswa sekolah dasar dan sekolah lanjutan, dan (2) mempertautkan dan menyesuaikan bahan yang berasal dari aneka cabang ilmu-ilmu sosial dan kehidupan masyarakat, sehingga menjadi bahan pelajaran yang mudah dicerna.

Berdasarkan deskripsi teori di atas, yang dimaksud dengan IPS adalah penyederhanaan disiplin ilmu-ilmu sosial dan segala sesuatu yang sifatnya sosial yang diorganisasikan secara ilmiah dan diajarkan di sekolah untuk mencapai tujuan pendidikan (nasional) khususnya dan pembangunan nasional pada umumnya.

Berdasarkan teori di atas, dapat disimpulkan bahwa hasil belajar Ilmu Pengetahuan Sosial adalah hasil yang telah dicapai oleh siswa dalam pembelajaran Ilmu Pengetahuan Sosial (IPS) sebagai akibat adanya latihan yang dilakukan oleh seseorang ataupun kematangan yang terjadi dalam dirinya dalam belajar Ilmu Pengetahuan Sosial. Karena luasnya bahasan mengenai hasil belajar, maka penelitian ini dibatasi pada hasil belajar kognitif.

\section{Metode Pembelajaran}

Metode menurut Salma (2008: 18) diartikan sebagai cara-cara atau teknik yang dianggap jitu untuk menyampaikan materi ajar. Dalam mendesain pembelajaran, metode inilah sebagai tolak ukur situasi belajar yang sesungguhnya.

Sedangkan pembelajaran menurut Dimyati \& Mudjiono dalam Sagala (2005: 18) mempunyai arti kegiatan guru secara terprogram dalam desain pembelajaran untuk membuat siswa belajar aktif yang menekankan pada penyediaan sumber belajar.

Jadi, metode pembelajaran adalah cara-cara atau teknik yang disajikan guru untuk siswa dalam proses kegiatan belajar secara terprogram dalam desain pembelajaran untuk melibatkan siswa aktif dan menekankan kepada penyediaan sumber belajar yang telah disediakan guru. Metode pembelajaran ada beberapa macam, diantaranya metode ceramah, tanya jawab, diskusi, demonstrasi, eksperimen, pemberian tugas, karyawisata, dan role playing. Penelitian ini hanya berfokus pada dua metode pembelajaran, yaitu metode pembelajaran ceramah dan role playing. 1. Metode Role Playing

Menurut Wahab (2008: 109), metode role playing adalah berakting sesuai dengan peran yang telah ditentukan terlebih dahulu untuk tujuan tertentu seperti menghidupkan kembali suasana historis, misalnya mengungkapkan kembali perjuangan para pahlawan kemerdekaan atau mengungkapkan kemungkinan keadaan yang akan datang, misalnya saja keadaan yang kemungkinan dihadapi karena semakin besarnya 
jumlah penduduk, atau menggambarkan keadaan imajiner yang dapat terjadi dimana dan kapan saja.

Jadi, dalam metode role playing, siswa 'memasuki' diri orang lain atau individu lain dan dengan perilaku seperti yang diperankannya, sehingga siswa akan memperoleh pengetahuan tentang orang dan motivasinya yang menandai perilakunya.

Untuk menggunakan metode role playing secara efektif dalam pebelajaran IPS, maka harus disadari dengan baik tujuan dari penggunaan metode bermain peran itu sendiri. Adapun tujuan digunakannya metode bermain peran (Fannie, dkk 1966: 27-47), diantaranya.

1) To help children understand that behaviour is caused.

2) To develop sensitivity to the feelings of other.

3) To release tension and feelings.

4) To diagnose the needs of children.

5) To improve the child's self concept.

6) To explore roles.

7) To explore the core values of American Culture.

8) To learn more about the functioning of the various subcultures in which different children live.

9) To help each clarify nis own frame of values for decision making.

10) To improve the social culture and value systems of the peer culture.

11) To develop 'group cohesiveness'.

12) To teach problem solving behaviour.

13) To develop the habit of considering consequences (consequential of causal thinking).

14) To teach the feeling, thinking, acting sequence.

\section{Metode Ceramah}

Metode ceramah diartikan sebagai metode yang tradisional, karena sejak dulu metode ini dipergunakan sebagai alat komunikasi lisan antara guru dengan anak didik dalam proses belajar mengajar. Meski metode ini lebih banyak melibatkan keaktifan guru daripada anak didik, tetapi metode ini tetap tidak bisa ditinggalkan begitu saja dalam kegiatan pengajaran. Metode ini mengupas suatu pokok permasalahan dalam pembelajaran secara lisan.

Menurut Santoso (2000: 81), metode ceramah adalah metode yang dilaksanakan oleh guru/ dosen dengan memberikan sejumlah informasi kepada sejumlah siswa/mahasiswa, di dalam atau di luar ruangan. Hal yang perlu diperhatikan adalah guru/ dosen harus menguasai bahan yang akan disajikan dan guru/ dosen diharapkan mampu memberikan selingan dengan humor supaya siswa/ mahasiswa tidak bosan, mengantuk, dan atau pasif. Guru/ dosen perlu membuat perencanaan yang sistematis supaya pembicaraannya berjalan lancar dan tidak tumpang tindih. Kemudian menurut Surakhmad (1986:77) bahwa "ceramah sebagai suatu metode mengajar ialah penerangan dan penuturan secara lisan oleh guru terhadap kelasnya."

Menurut Syah (2000: 203), "metode ceramah" dapat dikatakan sebagai suatu metode yang paling ekonomis untuk menyampaikan informasi. Di samping itu juga dipandang paling efektif dalam mengatasi kelangkaan literatur/ rujukan yang sesuai dengan jangkauan daya beli dan daya paham siswa. Hal ini karena metode ceramah hanya menggunakan lisan sebagai media penyampaian pesan. Oleh karenanya, tidak dibutuhkan biaya yang besar seperti halnya metode yang lainnya, misalnya metode eksperimen dan yang lainnya.

Berdasarkan deskripsi teori di atas, yang dimaksud dengan metode ceramah adalah cara mengajar yang memfokuskan pada penyampaian informasi oleh guru secara lisan, di mana kegiatan mengajar berpusat pada guru, sedangkan murid-murid menerima secara pasif.

\section{Kemandirian Belajar}

Kemandirian belajar menurut Karnita (2005:2), merupakan upaya strategis merajut masa depan diri dan bangsanya. Dari sikap ini diharapkan tumbuh kemandirian dalam bersikap, berwirausaha, berdemokrasi, bermasyarakat, berbangsa, dan bernegara. Kemandirian belajar diartikan sebagai suatu keadaan atau kondisi aktivitas belajar dengan kemampuan sendiri, tanpa bergantung kepada orang lain. Ia selalu konsisten dan bersemangat belajar di manapun dan kapanpun. Dalam dirinya sudah melembaga kesadaran dan kebutuhan belajar melampaui tugas, kewajiban dan target jangka pendek, serta nilai dan prestasi. Kondisi ini akan menyadarkan anak pada belajar sepanjang hayat.

Menurut Miarso (2004: 267), bahwa belajar mandiri prinsipnya sangat erat hubungannya dengan belajar menyelidik, yaitu berupa pengarahan dan pengontrolan diri dalam memperoleh dan menggunakan pengetahuan. Pendapat ini berarti kemampuan ini penting karena keberhasilan dalam kehidupan akan diukur dari kesanggupan bertindak dan berpikir sendiri, dan tidak tergantung kepada orang lain. Paling sedikit ada dua kemungkinan untuk melaksanakan prinsip ini, yaitu:

(1) digunakan program belajar yang mengandung petunjuk untuk belajar sendiri oleh peserta didik dengan bantuan guru yang minimal, dan

(2) melibatkan siswa dalam merencanakan dan melaksanakan kegiatan.

Menurut Good dalam Slamento, “Kemandirian 
belajar adalah belajar yang dilakukan dengan sedikit atau sama sekali tanpa bantuan dari pihak luar".

Berdasarkan uraian di atas, maka dapat disimpulkan bahwa kemandirian belajar adalah aktivitas belajar yang dilakukan oleh individu dengan kebebasannya dalam menentukan dan mengolah sendiri bahan ajar, waktu, tempat, dan memanfaatkan berbagai sumber belajar yang diperlukan. Dengan kebebasan tersebut, individu memiliki kemampuan dalam mengelola cara belajar, memiliki rasa tanggung jawab yang tinggi dan terampil memanfaaatkan sumber-sumber belajar.

Terdapat beberapa karakter kemandirian belajar. Karakter tersebut antara lain: (1) percaya diri; (2) tidak mengharap bantuan orang lain; (3) mau berbuat sendiri; (4) tanggung jawab; (5) ingin berprestasi tinggi; (6) menggunakan pertimbangan rasional dalam memberikan penilaian, mengambil keputusan serta memecahkan masalah, menginginkan rasa bebas; dan (7) selalu mempunyai gagasan baru.

\section{Hipotesis Penelitian}

Berdasarkan kajian teoretis dan kerangka berpikir sebagaimana telah diuraikan, maka hipotesis yang diajukan dalam penelitian ini dirumuskan sebagai berikut.

1. Hasil belajar antara siswa yang mengikuti pembelajaran dengan metode pembelajaran role playing lebih tinggi daripada hasil belajar siswa yang mengikuti pembelajaran dengan metode pembelajaran ceramah dalam mata pelajaran IPS di sekolah dasar.

2. Hasil belajar siswa yang memiliki kemandirian belajar tinggi dan siswa yang memiliki kemandirian belajar rendah terdapat perbedaan dalam mata pelajaran IPS di sekolah dasar.

3. Terdapat pengaruh interaksi antara metode pembelajaran dengan kemandirian belajar terhadap hasil belajar dalam mata pelajaran IPS di sekolah dasar.

4. Hasil belajar siswa yang memiliki kemandirian belajar tinggi yang mengikuti pembelajaran dengan metode pembelajaran role playing lebih tinggi daripada hasil belajar siswa yang mengikuti pembelajaran dengan metode pembelajaran ceramah dalam mata pelajaran IPS di sekolah dasar.

5. Hasil belajar siswa yang memiliki kemandirian belajar rendah yang mengikuti pembelajaran dengan metode pembelajaran ceramah lebih tinggi daripada hasil belajar siswa yang mengikuti pembelajaran dengan metode pembelajaran role playing dalam mata pelajaran IPS di sekolah dasar.

6. Hasil belajar antara siswa yang mengikuti pembelajaran dengan metode pembelajaran role playing antara siswa yang memiliki kemandirian belajar tinggi lebih tinggi dari siswa yang memiliki kemandirian belajar rendah.

7. Hasil belajar antara siswa yang mengikuti pembelajaran dengan metode pembelajaran ceramah antara siswa yang memiliki kemandirian belajar rendah lebih tinggi dari siswa yang memiliki kemandirian belajar tinggi.

\section{METODE PENELITIAN}

\section{Tujuan}

Penelitian ini dilakukan dengan tujuan untuk memperoleh fakta empirik tentang perbedaan hasil belajar Ilmu Pengetahuan Sosial (IPS) SD antara siswa yang diajar dengan menggunakan metode pembelajaran role playing dengan siswa yang diajar dengan menggunakan metode pembelajaran ceramah, dengan gaya belajar siswa yang memiliki kemandirian tinggi dan siswa yang memiliki kemandirian belajar rendah.

\section{Tempat dan waktu}

Penelitian ini dilaksanakan di SDN Pluit 05 Pagi, Jakarta Utara selama dua bulan. Satu bulan pertama, digunakan untuk uji coba instrumen dan pengolahan data agar diketahui tingkat validitas dan reliabilitas instrumen penelitian. Satu bulan berikutnya, pengambilan data di lapangan, dan analisis data. Adapun waktu penelitian akan dilaksanakan pada semester II tahun ajaran 2010/2011 dari bulan Januari 2011 - Februari 2011.

\section{Desain}

Metode penelitian yang digunakan adalah metode eksperimen dengan rancangan faktorial $2 \times 2$. Sebagai variabel terikat dalam penelitian ini dalah hasil belajar IPS. Sedangkan variabel bebas adalah metode pembelajaran, sedangkan variabel atributnya adalah kemandirian belajar. Desain eksperimen penelitian dapat digambarkan seperti pada tabel 1.

Tabel 1. Pola Eksperimen dengan Rancangan Group Factorial

\begin{tabular}{|c|r|c|}
\hline $\begin{array}{c}\text { Metode Pembelajaran } \\
(\mathrm{A})\end{array}$ & $\begin{array}{c}\text { Metode } \\
\text { Role } \\
\text { Playing } \\
\left(\mathrm{A}_{1}\right)\end{array}$ & $\begin{array}{r}\text { Metode } \\
\text { Ceramah } \\
\left(\mathrm{A}_{2}\right)\end{array}$ \\
\hline $\begin{array}{c}\text { Kemandirian Belajar } \\
(\mathrm{B})\end{array}$ & $\mathrm{A}_{1} \mathrm{~B}_{1}$ & $\mathrm{~A}_{2} \mathrm{~B}_{1}$ \\
\hline $\begin{array}{c}\text { Kemandirian Belajar Tinggi Rendah } \\
\left(\mathrm{B}_{1}\right)\end{array}$ & $\mathrm{A}_{1} \mathrm{~B}_{2}$ & $\mathrm{~A}_{2} \mathrm{~B}_{2}$ \\
\hline
\end{tabular}

Keterangan:

A1 : Kelompok siswa dengan metode pembelajaran role playing 
A2 : Kelompok siswa dengan metode pembelajaran ceramah

B1 : Kelompok siswa dengan kemandirian belajar tinggi

B2 :Kelompok siswa dengan kemandirian belajar rendah

A1B1 : Kelompok siswa dengan kemandirian belajar tinggi dan belajar dengan menggunakan metode role playing

A2B1 : Kelompok siswa dengan kemandirian belajar tinggi dan belajar dengan menggunakan metode ceramah

A1B2 :Kelompok siswa dengan kemandirian belajar rendah dan belajar dengan menggunakan role playing

A2B2 :Kelompok siswa dengan dengan kemandirian belajar rendah dan belajar dengan menggunakan metode metode ceramah

\section{Populasi dan Tehnik Pengambilan Sampel}

Populasi dalam penelitian ini adalah jumlah objek yang mempunyai karakteristik yang sama. Populasi target penelitian ini adalah seluruh siswa SD Negeri yang berada di wilayah Kecamatan Penjaringan, Jakarta Utara. Populasi terjangkau dalam penelitian ini adalah siswa SDN Pluit 05 Pagi, yaitu kelas VA sebanyak 30 siswa dan kelas VB sebanyak 30 siswa.

\section{HASIL DAN PEMBAHASAN}

Berdasarkan hasil penelitian, maka hasil pengujian hipotesis dapat dijelaskan sebagai berikut.

\section{Hipotesis Pertama}

Dalam penelitian ini ditemukan bahwa terdapat perbedaan hasil belajar IPS kelompok siswa yang diberi pembelajaran dengan metode pembelajaran role playing dan ceramah yang sangat signifikan, yaitu hasil belajar IPS siswa dengan metode role playing lebih tinggi dibandingkan dengan siswa dengan metode ceramah, sebab siswa dengan metode role playing belajar lebih bermakna karena siswa tersebut secara langsung memerankan tokoh dan mengalami proses pembelajaran dalam menemukan konsep sehingga siswa lebih bermakna dalam menerima materi pelajaran.

Untuk siswa dengan metode ceramah siswa tidak secara langsung mengalami penemuan konsep, sehingga pembelajaran kurang bermakna bagi siswa, mengakibatkan siswa tidak termotivasi untuk belajar.

\section{Hipotesis Kedua}

Pengujian hipotesis kedua menunjukkan, bahwa hasil belajar IPS antara anak yang memiliki kemandirian belajar tinggi lebih tinggi daripada siswa yang memiliki kemandirian belajar rendah. Perbedaan terjadi mengingat cara-cara khas yang digunakan siswa dalam menghadapi proses pembelajaran, yang meliputi; bagaimana siswa tersebut mempersiapkan pembelajaran, mengumpulkan informasi, memproses informasi, dan membuat keputusan yang dirasakan nyaman, sesuai, dan mantap, sehingga siswa tersebut menjadi lebih senang belajar, antara siswa yang memiliki kemandirian belajar tinggi berbeda dengan siswa yang memiliki kemandirian belajar rendah. Cara-cara yang berbeda ini tentunya dapat memberikan pencapaian hasil belajar yang berbeda pula.

Salah satu karakteristik siswa yang memiliki kemandirian belajar tinggi yang dapat menumbuhkan motivasi belajar adalah memiliki kemampuan dalam mengelola cara belajar, memiliki rasa tanggung jawab yang tinggi, dan terampil memanfaaatkan sumbersumber belajar. Siswa yang memiliki karakteristik ini pada saat mengikuti tes tentunya memiliki keinginan untuk memperoleh hasil lebih dibandingkan dengan yang lain. Untuk mewujudkan harapan ini, tentunya siswa tersebut berusaha untuk fokus memperbaiki diri dengan belajar. Sebaliknya siswa yang memiliki karakteristik dengan kemandirian belajar rendah, hasil yang diperoleh pada saat tes tidak akan menumbuhkan rasa persaingan dengan temannya, malah hasil yang diperolehnya dapat menurunkan motivasi belajar.

\section{Hipotesis Ketiga}

Pengujian hipotesis ketiga menunjukkan, bahwa kemampuan hasil belajar IPS bagi siswa dengan kemandirian belajar tinggi antara kelompok siswa yang diberi pembelajaran dengan metode role playing dan ceramah yang sangat signifikan, yaitu hasil belajar IPS siswa dengan metode role playing lebih tinggi dibandingkan dengan siswa dengan metode ceramah, hasil belajar IPS pembelajaran dengan metode role playing lebih tinggi daripada pembelajaran dengan metode ceramah sebagaimana hipotesis pertama menjadi semakin relevan walaupun kedua kelompok siswa tersebut sama-sama memiliki kemandirian belajar tinggi.

Secara teoretis dan empiris, pembelajaran dengan metode role playing lebih unggul pada pembelajaran yang membutuhkan berbagai penalaran dan keingintahuan yang tinggi karena siswa dengan kemandirian belajar tinggi selalu bertanggung jawab terhadap pembelajaran dan karakteristik lain yang dimiliki siswa dengan kemandirian belajar tinggi adalah dapat mengelola sumber belajar dengan baik. Siswa yang memiliki karakteristik ini akan dapat terus belajar walaupun mereka tidak mendapat petunjuk belajar yang terperinci, mereka akan tetap belajar dengan caranya sendiri. Sebaliknya siswa yang memiliki

Perspektif Ilmu Pendidikan - Vol. 25 Th. XVI April 2012 
karakteristik dengan kemandirian belajar rendah, apabila pada saat belajar tidak mendapat petunjuk yang terperinci, siswa akan kesulitan menghadapi permasalahan-permasalahan yang timbul. Seringnya menghadapi kesulitan tentunya dapat menurunkan hasil belajarnya.

\section{Hipotesis Keempat}

Pengujian hipotesis keempat menunjukkan bahwa hasil belajar IPS antara siswa yang memiliki kemandirian belajar tinggi jika pembelajaran menggunakan metode pembelajaran ceramah lebih rendah daripada siswa dengan kemandirian belajar rendah.

Beberapa ciri siswa yang memiliki kemandirian belajar rendah sebagaimana telah dikemukakan pada halaman depan, yakni sulit mengambil inisiatif dan mengatur atau mengorganisasikan dengan dirinya sendiri, mengharap bantuan orang lain , tidak bertanggung jawab, dan tidak dapat mengorganisasikan sendiri sumber belajarnya. Sulitnya mengambil inisiatif dan mengatur dirinya sendiri tentunya berpengaruh terhadap cara menguasai materi yang akan dipelajari sehingga hal ini dapat berpengaruh terhadap keberhasilan dalam menguasai materi pelajaran.

Siswa yang memiliki kemandirian belajar rendah mengikuti proses pembelajaran apa adanya, sehingga diperlukan tujuan pembelajaran yang tersusun dengan baik. Struktur materi pembelajaran juga cenderung diikuti sesuai dengan yang disajikan, sehingga diperlukan materi pembelajaran yang terstruktur dengan baik dan sistematis. Proses pembelajaran ceramah lebih menguntungkan bagi siswa yang memiliki kemandirian belajar rendah.

Siswa yang memiliki kemandirian belajar rendah cenderung untuk menerima struktur yang sudah ada, cenderung mengikuti tujuan yang sudah ada, cenderung bekerja dengan motivasi eksternal serta lebih tertarik pada penguatan eksternal, cenderung baik hati dan ramah, sehingga lebih mampu menjalin hubungan interpersonal dan lebih mudah diterima orang lain, kecenderungan untuk menerima informasi seperti yang disajikan menjadikan individu kemandirian belajar rendah terintegrasi dan cenderung lebih holistik.

Untuk pembelajaran dengan strategi role playing bagi siswa yang memiliki kemandirian belajar rendah cenderung akan membuat pembelajaran tidak bermakna karena kurang menantang sehingga dapat menurunkan motivasi yang berakibat dapat menurunkan hasil belajar siswa.

\section{Hipotesis Kelima}

Hasil penelitian pada pengujian hipotesis kelima menunjukkan, bahwa terdapat pengaruh inter- aksi antara metode pembelajaran dan kemandirian belajar terhadap hasil belajar IPS pada siswa. Artinya pengaruh interaksi antara metode pembelajaran dengan kemandirian belajar berpengaruh terhadap tinggi rendahnya hasil belajar IPS siswa SD. Perbedaan hasil belajar IPS yang mempunyai kemandirian belajar tinggi sebagaimana hipotesis kedua dikarenakan interaksi kemandirian belajar dengan perbedaan metode pembelajaran sebagaimana yang diuraikan dalam hipotesis pertama.

Kesimpulan ini lebih mempertegas kembali hasil pengujian hipotesis ketiga, bahwa hasil belajar IPS siswa yang belajar dengan metode pembelajaran role playing lebih rendah dari siswa yang belajar dengan metode ceramah yang sama-sama memiliki kemandirian belajar rendah dinyatakan signifikan. Oleh karena itu, kemandirian belajar menentukan anak menjadi lebih baik dalam perolehan hasil belajar IPS siswa.

\section{Hipotesis keenam}

Hasil penelitian pada pengujian hipotesis keenam menunjukkan, bahwa hasil belajar siswa yang mengikuti pembelajaran dengan strategi role playing bagi siswa yang memiliki kemandirian belajar tinggi lebih tinggi dari siswa yang memiliki kemandirian belajar rendah.

\section{Hipotesis ketujuh.}

Hasil penelitian pada pengujian hipotesis ketujuh menunjukkan, bahwa hasil belajar siswa yang mengikuti pembelajaran dengan metode ceramah yang memiliki kemandirian belajar rendah lebih tinggi dari siswa yang memiliki kemandirian belajar tinggi.

\section{Keterbatasan Penelitian}

Penelitian ini telah dilakukan secara maksimal dengan berpegang teguh kepada prinsip-prinsip penelitian ilmiah. Namun, baik dari aspek teoretik maupun praktisnya, masih terdapat keterbatasan-keterbatasan, yang diduga mempengaruhi hasil penelitian. Keterbatasan yang dimaksud, yaitu penelitian ini membatasi diri pada variabel metode pembelajaran (role playing dan ceramah), kemandirian belajar (kemandirian belajar tinggi dan rendah), dan pengaruhnya terhadap hasil belajar IPS siswa SD Kelas V. Padahal masih banyak variabel-variabel yang dapat mempengaruhi hasil belajar yang tidak dikontrol melalui penelitian ini. Misalnya, motivasi, jenis kelamin, disiplin belajar, dan banyaknya waktu yang digunakan untuk kepentingan belajar, dan sebagainya.

Keterbatasan penelitian seperti yang telah dipaparkan di atas, hendaknya dijadikan pertimbangan bagi para peneliti selanjutnya atau untuk dijadikan 
rujukan dari hasil penelitian ini bagi pengembangan khazanah pengetahuan bagi para pembaca. Temuan penelitian ini bukanlah dijadikan ajang perdebatan, tetapi dapat dijadikan masukan bagi penelitian selanjutnya agar menghasilkan penelitian yang lebih sempurna untuk perbaikan dan peningkatan mutu pembelajaran IPS di sekolah dasar pada masa-masa mendatang.

\section{PENUTUP}

\section{Kesimpulan}

Berdasarkan penelitian yang telah dilakukan, maka dapat disimpulkan sebagai berikut.

Pertama, hasil belajar IPS siswa yang diberikan melalui pembelajaran dengan metode pembelajaran role playing lebih tinggi dibandingkan dengan siswa yang diberikan pembelajaran dengan metode pembelajaran ceramah di SDN 05 Pluit, Penjaringan, Jakarta Utara.

Kedua, hasil belajar IPS siswa yang memiliki kemandirian belajar tinggi lebih tinggi dibandingkan dengan siswa yang memiliki kemandirian belajar rendah di SD Negeri 05 Pluit, Penjaringan, Jakarta Utara.

Ketiga, hasil belajar IPS bagi siswa dengan kemandirian belajar tinggi antara kelompok siswa yang diberi pembelajaran dengan metode pembelajaran role playing dan ceramah yang sangat signifikan, yaitu hasil belajar IPS siswa dengan metode pembelajaran role playing lebih tinggi dibandingkan dengan siswa dengan metode pembelajaran ceramah.

Keempat, hasil belajar siswa yang mengikuti pembelajaran dengan metode pembelajaran role playing bagi siswa yang memiliki kemandirian belajar tinggi lebih tinggi dari siswa yang memiliki kemandirian belajar rendah.

Kelima, hasil belajar siswa yang mengikuti pembelajaran dengan metode pembelajaran ceramah yang memiliki kemandirian belajar rendah lebih tinggi dari siswa yang memiliki kemandirian belajar tinggi.

\section{Saran}

Berdasarkan penelitian yang telah dilakukan, maka dapat dikemukakan saran-saran sebagai berikut.

Pertama, guru sebaiknya lebih mampu menstimulasi dan melatih kemampuan dalam mengajarkan IPS dengan memberikan kebebasan seluas-luasnya kepada siswa untuk berekspresi dan mengembangkan potensi dirinya.

Kedua, pengembangan strategi pembelajaran yang berpusat kepada siswa, hendaknya dilakukan dengan memperhatikan cara berpikir siswa, sehingga siswa mampu mengoptimalkan kemampuan diri serta mendukung proses menuju kematangan kemampuannya.

Ketiga, diharapkan guru dapat membuat beragam latihan dan metode yang sesuai dengan karakteristik siswa tanpa harus membedakan latar belakang status sosial ekonomi siswa.

Keempat, diharapkan guru mengoptimalkan sarana yang ada sebagai media dan alat pembelajaran dalam rangka meningkatkan hasil belajar IPS.

Kelima, orang tua diharapkan dapat memberikan pendidikan kepada anaknya untuk mampu meningkatkan kemampuan anak sesuai dengan tingkat perkembangan anak.

Keenam, membiasakan siswa untuk dapat berekspresi secara bebas dan bertanggungjawab dalam segala hal. Menyediakan media-media yang disukai siswa sebagai sarana untuk menyampaikan pandangan, dengan memperhatikan kemandirian belajar siswa.

\section{DAFTAR PUSTAKA}

Anderson, L. W \& Krathwohl, D.R. (2001). Taxonomy for learning teaching and assessing, a revision of Bloom's taxonomy of educational objectives. New York: Addison Wesley Longman, Inc

Bloom, B. S. (1956). Taxonomy of objectives: The clasification of educational goals. New York: Longman Inc.

Daldjoeni. (1992). Dasar-dasar ilmu pengetahuan sosial: Untuk mahasiswa IKIP (FKIP) dan guru sekolah lanjutan. Bandung: Alumni.

Dimyati \& Mudjiono. (2002). Belajar dan pembelajaran. Jakarta: Pusat Perbukuan, Depdikbud dan PT. Rineka Cipta.

Fannie, Shaftel \& Shaftel, G. (1966). Role playing for social values: Decision making in the social studies. New Jersey: Englewood Cliffs, Prntice Hall.

Karnita. (2005). Kemandirian belajar. Jakarta: Pikiran Rakyat.

Kurikulum Tingkat Satuan Pendidikan. Jakarta: Pusat Kurikulum.

Miarso, Y. H. (2004). Menyemai benih teknologi pendidikan. Jakarta:Kencana.

Mutakin, A. (1997). Pendidikan ilmu sosial. Jakarta: Dikdasmen, Depdikbud.

Panen, P. (1994). Belajar mandiri (Mengajar di Perguruan Tinggi). PAU PPAI Jakarta: Dirjen Dikti, Depdikbud.

Prawiradilaga, D. S. (2008). Prinsip desain pembelajaran. Jakarta: Universitas Negeri Jakarta, 2008

Santoso, S. (2000). Problematika pendidikan dan cara pemecahannya. Jakarta: Kreasi Pena Gading.

Surachmad, W. (1986). Metodologi pengajaran nasional. Bandung: Jemmars.

Perspektif Ilmu Pendidikan - Vol. 25 Th. XVI April 2012 
Pengaruh Metode Pembelajaran...

Syah, M. (1995). Psikologi pendidikan: Suatu pendekatan baru. Bandung: Remaja Rosdakarya.

Undang-undang Repubik Indonesia Nomor 20 Tahun 2003, tentang Sistem Pendidikan Nasional. Jakarta:
Cv. Medya Duta

Wahab, A. A. (2008). Metode dan model-model mengajar IPS. Bandung: Alfabetha. 2008 